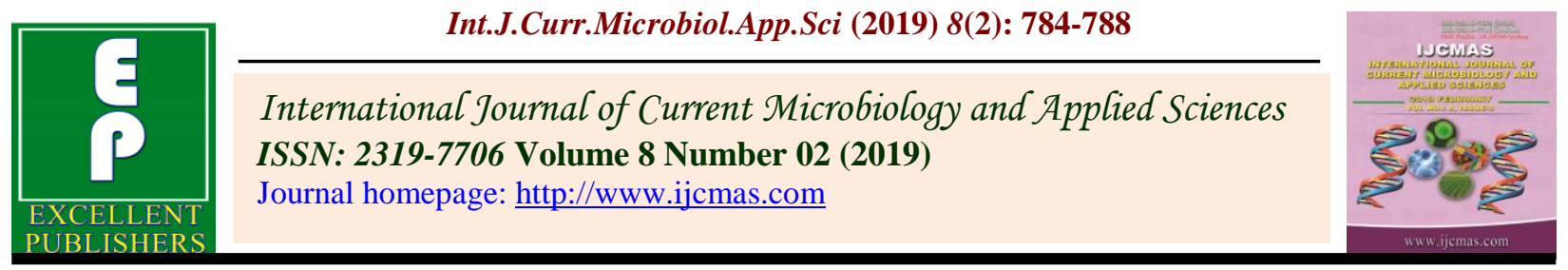

Original Research Article

https://doi.org/10.20546/ijcmas.2019.802.090

\title{
Drum Seeder a Promising Low Cost Technology in Rice Production System for Small and Marginal Farmers of Mahabubnagar District, India
}

\author{
J.S. Sudharani ${ }^{1 *}$, K. Aruna ${ }^{2}$ and A. Ramakrishna Babu ${ }^{3}$ \\ ${ }^{1}$ Crop Production, ${ }^{2}$ Agriculture Extension, ${ }^{3}$ Plant Protection, District Agricultural Advisory \\ and Transfer of Technology Centre, Mahabubnagar, PJTSAU Telangana, India \\ *Corresponding author
}

\begin{tabular}{|l|}
\hline Ke y w or d s \\
Rice, Drum seeder, \\
MTU1010 \\
\hline Article Info \\
\hline Accepted: \\
07 January 2019 \\
Available Online: \\
10 February 2019 \\
\hline
\end{tabular}

\section{A B S T R A C T}

The present investigation was conducted in order to reduce labour as well as input cost for rice cultivation of rice growing predominantly small and marginal farmers of Mahabubnagar district of Telangana State of India. Eight row rice drum seeder was introduced and evaluated on farmer's field during kharif 2013, 2014 and 2015 years. The seeder consists of eight seed drum made up of fiber which required only one operator to do the seeding. Two varieties viz., MTU1010 and Tellahamsa were sown. The seed was pre soaked for 24 hours followed by incubation for 12 hours to just germinate the seed. The seed drum was filled up to $34^{\text {th }}$ capacity and the drum seeder is dragged on uniformly leveled field and for management of weeds, pre and post emergence herbicides like Oxadiarzyl and pyrazosulfuran ethyl in combination mechanical weeding with cono weeder were implemented to control the weeds On an average this improved technology recorded $8 \%$ higher grain yield $(6096 \mathrm{~kg} / \mathrm{ha})$ as compared to farmers local practices $(5677$ $\mathrm{kg} / \mathrm{ha})$ Reasons for good performance were optimum plant density in drum seeder $(52$ hills $\left./ \mathrm{m}^{2}\right)$, as compared to control $\left(29\right.$ hills $\left./ \mathrm{m}^{2}\right)$, productive tiller were more $\left(354 / \mathrm{m}^{2}\right)$ in drum seeder, than the control $\left(266 / \mathrm{m}^{2}\right)$. In addition to increase in yield, the improved technology gave higher net return, benefit/cost ratio and reduction in cultivation costs than farmers' practices. Direct sowing by drum seeder in 8 rows facilitated to take up organic fertilizer application, plant protection measures and weed control in an efficient manner. Further the crop duration is reduced around one weak in direct sown rice as compared to normal transplanted which facilitated to raise other crop. The farmers in OFTs had realized that direct sowing by drum seeder is only a viable option to reduce cost of cultivation of rice and increase net return due to less seed rate, less labour requirements at the time of sowing and no need of nursery raising etc.

\section{Introduction}

Rice is the staple food of more than half of the world's population. India, the second largest producer after China, has an area of over 43.95 million hectares under rice with production and yield of 106.29 million tones and $2424 \mathrm{~kg}$ per hectare of rice respectively in 2013-14 (DES, 2014). Among the cultivation techniques method of establishment is one of the important practice which decides the cost of cultivation, Direct seeding with drum seeder avoids any raising of nursery, pulling up seedlings and transplanting them so that 
labour requirement for crop establishment is negligible. The difficulties in nursery raising, drudgery in transplanting, uncertainty in rainfall and lack of water in tanks and wells during nursery raising and labour shortage in nursery raising and transplanting time necessitated for alternate method of rice cultivation (Murumkar et al., 2014).In transplanted rice which is a labour intensive and expensive can be replaced by direct seeding that can reduce the labour needs by 20\% (Pradhan, 1969 and Santhi et.al., 1998). Direct seeding in rice is identified as viable technology to overcome the problem of high cost of production and to mitigate flood and drought situation in nursery season. The present investigation was conducted in order to reduce labour as well as input cost for rice cultivation of rice growers predominantly small and marginal farmers of Mahabubnagar district of Telangana State of India. Eight row rice drum seeder was introduced and evaluated on farmer's field during kharif 2013, 2014 and 2015 years.

\section{Materials and Methods}

The present investigation was conducted in order to reduce labour as well as input cost for rice cultivation of rice growing predominantly small and marginal farmers of Mahabubnagar district of Telangana State of India. The drum seeder developed by PJTSAU was assessed by DAATTC, in sandy clay loam soils during kharif 2013-2015. Drum seeder consists of four seed drums made of plastic mounted over a shaft, ground wheels, floats and handle. The seed drum is cylindrical shape with $200 \mathrm{~mm}$ diameter nine numbers of seed metering hole (funnel shaped) of $8 \mathrm{~mm}$ diameter were provided along the circumference of the drum at both the ends with row to row spacing of $20 \mathrm{~cm}$. The cost of the unit was Rs.4200/-. Advantages are uniformity in seed sowing, reduction in seed rate and cost of thinning is reduced, hill dropping of the seed is achieved and continuous drilling is eliminated. drum seeder was evaluated against the conventional transplanted paddy. Drum seeder is light in weight, easy to operate and more area can be covered by a single man. The seeds are dropped in rows @ $20 \mathrm{~cm}$ row to row spacing and the seed rate is about $37.5 \mathrm{~kg}$ per hectare of variety of rice was taken in the experimentation. Advantages of drum seeder is uniformity in seed sowing, reducing thinning cost, hill dropping of the seed can be achieved with this improved system of planting. Farmers can take up paddy cultivation at any time, right away, as there is no requirement or delay of raising a nursery. Paddy cultivation using direct seeding method can be taken up in fields which have heavy weed infestation, although this means that herbicide application is a must. Details of the direct-seeding technology.

\section{Results and Discussion}

Sprouted paddy seeds were sown using eight row paddy drum seeder. The test conditions during the trials are given in Table 1 . The pregerminated seeds were filled in the drums and the seeder was operated in the puddle field condition. The combination of $75 \%$ drum fill and $1.5 \mathrm{~km} / \mathrm{h}$ travel speed was used field test of the eight row paddy drum seeder. The field performance of the paddy drum seeder is presented in Table 1. Based on the field trials conducted during kharif 2013, 2014 and 2015, it was observed that the On an average this improved technology recorded $8 \%$ higher grain yield $(6096 \mathrm{~kg} / \mathrm{ha})$ as compared to farmers local practices $(5677 \mathrm{~kg} / \mathrm{ha})$ Reasons for good performance were optimum plant density in drum seeder $\left(52 \mathrm{hills} / \mathrm{m}^{2}\right)$, as compared to control $\left(29\right.$ hills $\left./ \mathrm{m}^{2}\right)$, productive tiller were more $\left(354 / \mathrm{m}^{2}\right)$ in drum seeder, than the control $\left(266 / \mathrm{m}^{2}\right)$. In addition to increase in yield, the improved technology gave higher net return, benefit/cost ratio and reduction in cultivation costs than farmers' 
practices. Direct sowing by drum seeder in 8 rows facilitated to take up organic fertilizer application, plant protection measures and weed control in an efficient manner. Further the crop duration is reduced around one weak in direct sown rice as compared to normal transplanted which facilitated to raise other crop. The farmers in OFTs had realized that direct sowing by drum seeder is only a viable option to reduce cost of cultivation of rice and increase net return due to less seed rate, less labour requirements at the time of sowing and no need of nursery raising etc. (Fig. 1, Table 2 and 3)

Table.1 Differences between conventional and direct-seeding with drum seeder methods

\begin{tabular}{|c|c|c|c|}
\hline S.No & Particular & $\begin{array}{l}\text { Direct seeding with } \\
\text { drum seeder }\end{array}$ & Normal transplanting \\
\hline 1. & Seed rate & 25 to $30 \mathrm{~kg} / \mathrm{ha}$ & 80 to $100 \mathrm{~kg} / \mathrm{ha}$ \\
\hline 2. & Cost of nursery raising & 0 & Rs. 3500/- \\
\hline 3. & Days to transplantimg & 0 & 25 to 30 days \\
\hline 4. & $\begin{array}{l}\text { Labour requirement to } \\
\text { planting /seeding } \\
\text { (mandays/ha) }\end{array}$ & 2 & 12 \\
\hline 5. & Spacing & $22.5 \times 8 \mathrm{~cm}$ & Zig -zag \\
\hline 6. & Water management & $\begin{array}{l}\text { No standing water after } \\
\text { seeding, the field is kept } \\
\text { at saturation up to } \\
\text { maximum tillering and } \\
\text { there after } 2-3 \mathrm{~cm} \\
\text { standing water till } 10 \text { days } \\
\text { before harvesting }\end{array}$ & $\begin{array}{l}5 \mathrm{~cm} \text { or more standing water } \\
\text { from the day of } \\
\text { transplantation to } 10 \text { days } \\
\text { before harvesting }\end{array}$ \\
\hline 7. & Weed management & $\begin{array}{l}\text { Application of herbicide is } \\
\text { a must once or twice. } \\
\text { Oxadiargyl } 75 \mathrm{~g} / \mathrm{ha} \text { or } \\
\text { pyrazosulfuan @ } 200 \mathrm{~g} / \mathrm{ha} \\
3 \text { days after seeding, and } \\
\text { if necessary 2.4-D. } \\
\text { Sodium salt application at } \\
30-35 \text { days after seeding. } \\
\text { Conoweeder is run in one } \\
\text { direction only, either E-W } \\
\text { or N-S, i.e., in the } \\
\text { direction in which the } \\
\text { drum-seeder was pulled. }\end{array}$ & $\begin{array}{l}\text { Manual weeding twice (or) } \\
\text { application of herbicide } 1 \text { st } \\
\text { time and manual weeding } \\
\text { 2nd time. }\end{array}$ \\
\hline
\end{tabular}

PJTSAU: Package of practices, Vyavasaya panchangam 2014 
Table. 2 Grain yield of rice as influenced by method of establishment

\begin{tabular}{|c|c|c|c|c|c|c|c|}
\hline \multirow{2}{*}{$\begin{array}{c}\text { Average } \\
\text { Yield }\end{array}$} & \multicolumn{2}{|c|}{ No. of Hills/m } & \multicolumn{2}{c|}{ Productive tiller } & \multicolumn{2}{c|}{ Yield (kg/ha) } & \multirow{2}{*}{ increase } \\
\cline { 2 - 8 } & Treatment & Control & Treatment & Control & Treatment & Control & \\
\hline Kharif 2013 & 53 & 33 & 349 & 264 & 6358 & 5795 & 9.7 \\
\hline Kharif 2014 & 52 & 28 & 358 & 272 & 6239 & 5835 & 6.9 \\
\hline Kharif 2015 & 53 & 27 & 355 & 263 & 5693 & 5401 & 5.4 \\
\hline Pooled results & 52 & 29 & 354 & 266 & 6096 & 5677 & 7.3 \\
\hline
\end{tabular}

Table.3 Economic parameters of paddy as influenced by method of establishment

\begin{tabular}{|c|c|c|}
\hline Economic parameters/ Treatment details & Drum Seeder & Normal Transplanting \\
\hline Average Yield (kg/ha) & 6096 & 5677 \\
\hline Input cost (Rs.) & 33850 & 38625 \\
\hline Average net returns (Rs.) & 80017 & 69392 \\
\hline B:C ratio & 2.4 & 1.8 \\
\hline
\end{tabular}

Fig.1

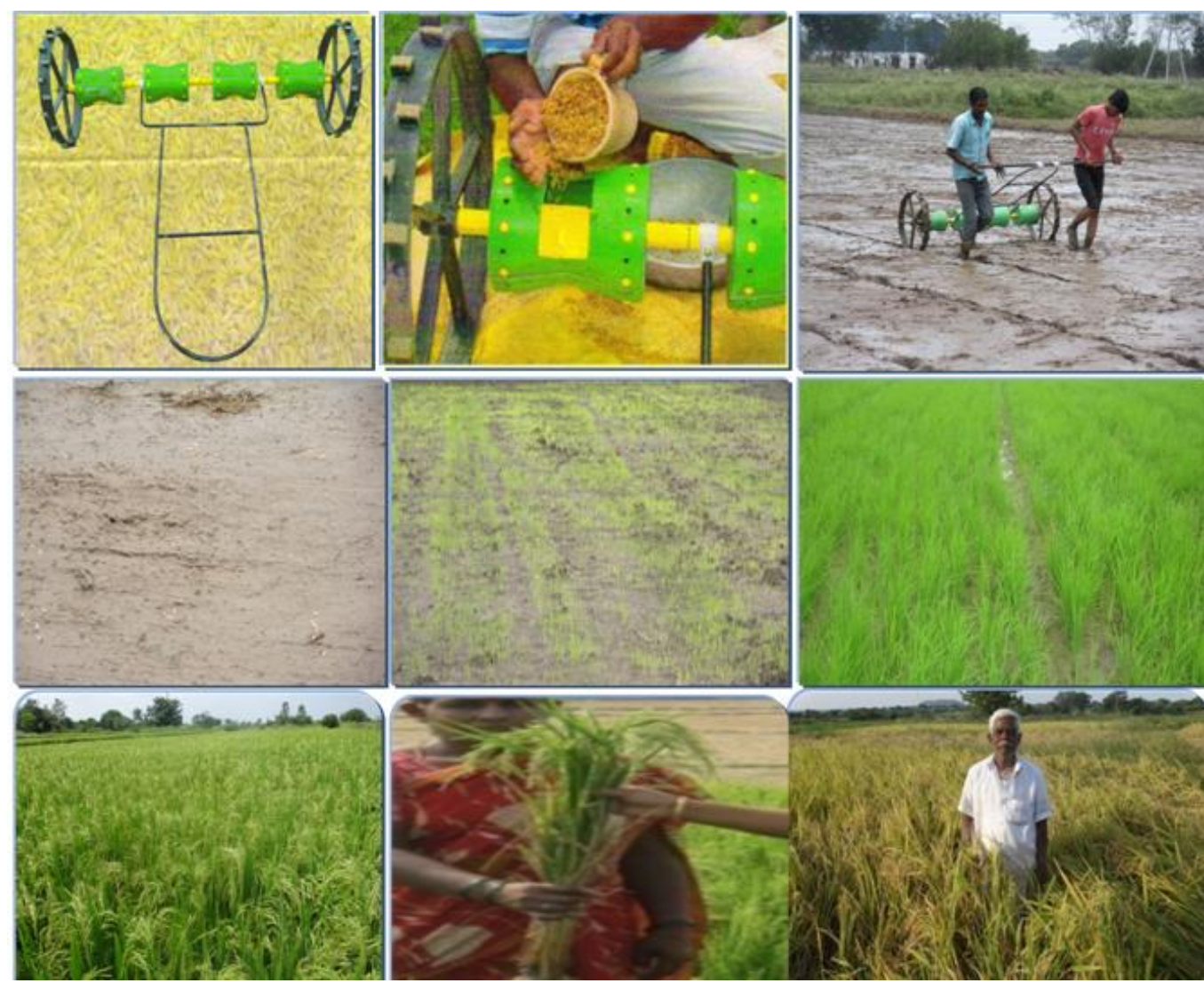

a) drum seeder, b) filling the drum with sprouted seed, c) Pulling the seeder on puddled and levelled field ,

d) sprouted seed, e) early establishment, f) Tillering stage, Flowering stage, g) Farmer with the sheaves

i) farmer at harvest stage of crop 
It can be concluded that direct sowing with drum seeder can help when there is a shortage of labour for transplanting, increases the yield, reduces the crop duration, drudgery and cost of cultivation.

\section{References}

Anonymous, Pocket Book of Agricultural Statistics. Ministry of Agriculture. GOI. Directorate of Economics and Statistics, Department of Agriculture and Cooperation (DAC) New Delhi (2014).

P Santhi, K Ponnuswamy and N K Chetty (1998). Effect of seeding methods and efficient nitrogen management practices on the growth of lowland rice. J. of Ecobiol. 10(2): pp 123-132.

R.P. Murumkar Usha R. Dongarwar, P.S. Pisalkar D.S. Phad (2014), Evaluation of field performance of eight row paddy drum seeder international journal of innovative science, engineering \& technology Vol. 1 Issue 9.

S.N Pradhan (1969), Mechanization of rice cultivation.

Vyavasaya panchangam PJTSAU: Rice Package of practices, 2014.

\section{How to cite this article:}

Sudharani, J.S., K. Aruna and Ramakrishna Babu, A.2019. Drum Seeder a Promising Low Cost Technology in Rice Production System for Small and Marginal Farmers of Mahabubnagar District, India. Int.J.Curr.Microbiol.App.Sci. 8(02): 784-788.

doi: https://doi.org/10.20546/ijcmas.2019.802.090 